\title{
The effectiveness of a weight loss diet in a group of overweight and obese women with recurrent depressive disorders
}

\author{
Ewa Stefańska ${ }^{1}$, Agnieszka Wendołowicz $^{1}$, Beata Konarzewska², Lucyna Ostrowska ${ }^{1}$ \\ ${ }^{1}$ Department of Dietetics and Clinical Nutrition, Medical University of Bialystok, Bialystok, Poland \\ ${ }^{2}$ Department of Psychiatry, Medical University of Bialystok, Bialystok, Poland
}

\begin{abstract}
Introduction: The research conducted among patients with depression shows that such patients commit a range of nutritional mistakes which may predispose them to the development of many diseases including obesity and its complications.

Aim of the study was to assess the effectiveness of a balanced weight loss diet in a group of women with recurrent depressive disorders.

Material and methods: 60 women suffering from depression, aged 41-64 (mean $52 \pm 5.3$ ) on a six-month weight loss diet took part in the study. The patients' nutrition was assessed both in terms of quality and quantity, they were also subjected to anthropometric tests and their body composition was analysed.

Results: An average reduction in the women's body weight was $4.1 \pm 3.1 \mathrm{~kg}$. The percentage content of the fatty tissue was reduced by $2.5 \pm 1.1 \%$ on average after modification of the nutrition (a statistically significant decrease in the frequency of wheat bread, cream, fat pork and eggs was observed). A considerable reduction in the mean energy value of the diet and a decrease in the total fat supply was also implemented.

Conclusions: It seems that the dietary procedure which is aimed at obtaining the most advantageous effects of the reduction in the body mass of obese patients suffering from depression should be based not only on proper selection of food products and reduction in the energy value of the diet, but it should also take into account actions aimed at introducing permanent lifestyle changes including increased motivation of the patients to undertake physical activity.
\end{abstract}

Key words: depression, overweight, obesity, reducing diet.

\section{Introduction}

Eating disorders which result in obesity may take part in pathogenesis of depressive disorders like a depressed mood caused by obesity. The relation between obesity and depression may vary in middle-aged and elderly adults as compared to young adults, as functional limitations and co-existing diseases connected, for example, with the ageing process, may lead to obesity and may also be related to mood changes [1]. The relation between obesity and depression was the subject of many studies, however, the results of these studies are contradictory. In McCrea's research, a positive relation between depressive disorders and the BMI in young women was observed [2]. In prospective observational studies, the existence of a relationship between the quality of the diet and depression and obesity was found [3]. The most frequent cause of obesity is improper eating habits which include conditioned and unconditioned responses as well as emotional and mental ones which present a person's behaviour towards food $[4,5]$.
Recurrent depressive disorders, just like obesity, lead to numerous health complications. At present, the occurrence of both conditions is observed more and more often. According to a WHO report, approx. 300 million people have been diagnosed with obesity [6]. Recurrent depressive disorders also belong to the most frequent pathological conditions occurring in the population. The risk of contracting the disease affects at least $10 \%$ of the adult population and is twice as high in women [7].

The aim of the study was to assess the effectiveness of using a reduction diet by perimenopausal women over a six-month observation period.

\section{Material and methods}

The study was conducted among 60 women treated for recurrent depressive disorders who reported to the Mental Health Outpatient Clinic at the Psychiatry Clinic of the Medical University of Biatystok in the period from January to December 2014. Women aged 41-64 
(mean: $52 \pm 5.3$ years of age), whose average BMI at the moment the program started was $30.5 \pm 3.6 \mathrm{~kg} / \mathrm{m}^{2}$. The main criterion for the selection of the group for tests was recurrent depressive disorders (diagnosed by a psychiatrist), according to the International Classification of Diseases (ICD-10) [8]. The course of the disease up to date was assessed on the basis of the medical history and available medical documentation. The intensity of depression was assessed using the Hamilton Depression Scale (the 17-point version) [9] as well as the Beck's self- assessment scale [10]. Both patients with the first depressive episode (F32.0-F32.2) and patients with subsequent episodes with recurring depressive disorders (F33) were included in the study. The total duration of the disease was not longer than 5 years. The anti-depression treatment in progress included one antidepressant and possibly one sedative used on an as-needed basis. Persons with a diagnosed depressive episode secondary to the bipolar affective disorder, organic disorders of the central nervous system, addiction to psychoactive substances as well as with severe somatic diseases which can have a negative effect on the mood were excluded from the study.

Patients taking part in the study were informed about the purpose and methodology of the research and each patient expressed her written consent to the participation in the study. This research was approved by the local Bioethical Committee (Approval No. R-I002/370/2014).

The patients' nutrition was assessed twice (during the baseline visit and after 6 months). During the baseline visit, before starting the dietary procedure, each patient was provided nutritional advice, the recommended low-energy diet was discussed, and the patients received a weekly meal plan with the daily calorie intake ranging from 1200 to $1500 \mathrm{kcal}$. Individual meetings were also held during which the patients learned how to calculate calories according to household measures and calorie content of basic food products. Check-up visits were held every month; eating habits were assessed and adjusted during those visits. The eating habits were assessed using a questionnaire developed at the Department of Dietetics and Clinical Nutrition, Medical University of Biatystok. The questionnaire included questions, amongst other things, concerning the patients' sociodemographic situation and questions concerning the frequency of eating selected food products. The quantitative assessment of the diet was conducted using three-day diaries kept by the patients before their appointment with the dietician. The computer program Dieta 5.0 developed by the Food and Nutrition Institute in Warsaw was used for the assessment of the nutritional value of daily food rations. The sizes of portions of products and dishes were assessed using the "Album of photographs of products and dishes" prepared by the Food and Nutrition Institute in Warsaw [11]. During the baseline visit and after 6 months of research, both the body weight and the waist perimeter were measured, and the body composition was analysed using a MALTRON BioScan 920-2 device manufactured by Maltron International TLD using electrical bioimpedance.

The final results were presented in the form of the arithmetic mean, standard deviation and percentage calculations. The statistical assessment of the results obtained was performed using STATISTICA 10.0 by StatSoft (using the $\chi^{2}$ test and Wilcoxon's signed-rank test). The relationship between selected variables was evaluated using the Spearman correlation coefficient, $p<0.05$ was adopted as the significance level in all the calculations.

\section{Results}

Women with excessive body weight took part in this study: $50 \%$ of the subjects were overweight wom-

Tab. I. Body weight, BMI, body composition of women suffering from depression before and after 6 months of diet

\begin{tabular}{lccc}
\hline \multirow{2}{*}{ Variables } & Before intervention & After intervention & Mean \pm SD \\
\cline { 2 - 4 } & Mean \pm SD & $76.5 \pm 11.3$ & 0.0581 \\
\hline Body weight $(\mathrm{kg})$ & $80.6 \pm 13.6$ & $29.5 \pm 3.0$ & 0.1272 \\
\hline Body mass index $\left(\mathrm{kg} / \mathrm{m}^{2}\right)$ & $30.5 \pm 3.6$ & $100.5 \pm 6.7$ & 0.1780 \\
\hline Waist circumference $(\mathrm{cm})$ & $104.0 \pm 10.4$ & $37.7 \pm 4.7$ & 0.7753 \\
\hline Fat mass $(\%)$ & $40.2 \pm 5.4$ & $28.9 \pm 1.4$ & 0.0557 \\
\hline Fat mass $(\mathrm{kg})$ & $33.9 \pm 9.1$ & $62.2 \pm 7.5$ & 0.2449 \\
\hline Fat free mass $(\%)$ & $57.9 \pm 5.3$ & $47.6 \pm 4.4$ & 0.2739 \\
\hline Fat free mass (kg) & $46.7 \pm 4.9$ & $283.9 \pm 113$ & 0.2616 \\
\hline VAT (cm $\left.{ }^{2}\right)$ & $358.4 \pm 140.38$ & $130.4 \pm 33.4$ & $2.2 \pm 1.4$ \\
\hline SAT (cm $\left.{ }^{2}\right)$ & $133.0 \pm 38.2$ & $48.8 \pm 3.0$ & 0.2943 \\
\hline VAT/SAT & $2.7 \pm 1.7$ & $47.4 \pm 4.3$ & 0.2052 \\
\hline Total body water (\%) & &
\end{tabular}


Tab. II. Assessment of the frequency of consumption of selected food products by obese patients suffering from depression before and after dietary intervention

\begin{tabular}{|c|c|c|c|c|c|c|c|c|c|c|c|c|c|}
\hline \multirow[b]{2}{*}{ Product } & \multicolumn{6}{|c|}{ Before dietary intervention (\%) } & \multicolumn{6}{|c|}{ After dietary intervention (\%) } & \multirow[b]{2}{*}{$p$} \\
\hline & $\begin{array}{l}\text { ते } \\
\text { ते } \\
\text { ते } \\
\text { 岁 }\end{array}$ & 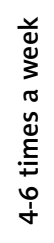 & 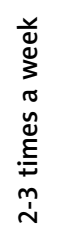 &  &  & 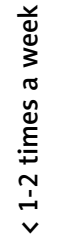 & 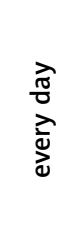 & 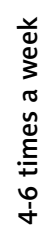 & 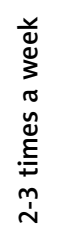 & 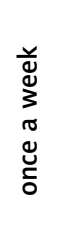 & 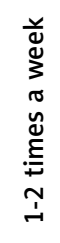 & 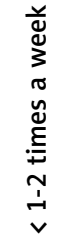 & \\
\hline Grits & 0 & 4 & 18 & 26 & 36 & 16 & 0 & 0 & 16 & 36 & 36 & 12 & 0.2044 \\
\hline Wheat bread & 52 & 12 & 14 & 6 & 10 & 6 & 40 & 24 & 24 & 8 & 4 & 0 & 0.0115 \\
\hline Wholemeal bread & 0 & 2 & 14 & 42 & 32 & 10 & 4 & 16 & 36 & 44 & 0 & 0 & 0.0475 \\
\hline Milk & 28 & 18 & 20 & 14 & 6 & 14 & 40 & 8 & 16 & 20 & 8 & 8 & 0.0334 \\
\hline Cottage cheese & 10 & 20 & 24 & 30 & 10 & 6 & 4 & 16 & 28 & 40 & 8 & 4 & 0.2898 \\
\hline Yellow cheese & 6 & 12 & 40 & 18 & 16 & 8 & 4 & 12 & 32 & 36 & 12 & 4 & 0.1367 \\
\hline Yoghurt/kefir & 18 & 26 & 24 & 16 & 6 & 10 & 24 & 24 & 24 & 16 & 12 & 0 & 0.2735 \\
\hline Cream & 6 & 14 & 42 & 20 & 10 & 8 & 8 & 20 & 44 & 20 & 8 & 0 & 0.0117 \\
\hline Fat pork & 12 & 4 & 30 & 52 & 2 & 0 & 8 & 8 & 20 & 8 & 56 & 0 & 0.0111 \\
\hline Lean pork & 8 & 26 & 40 & 20 & 6 & 0 & 8 & 40 & 36 & 8 & 8 & 0 & 0.0295 \\
\hline Beef & 0 & 0 & 0 & 2 & 18 & 80 & 0 & 0 & 4 & 8 & 16 & 72 & 0.0149 \\
\hline Chicken/turkey & 0 & 14 & 50 & 26 & 2 & 8 & 0 & 16 & 48 & 24 & 4 & 8 & 0.6352 \\
\hline Goose & 0 & 0 & 2 & 0 & 8 & 90 & 0 & 0 & 0 & 0 & 4 & 96 & 0.4202 \\
\hline Sea fish & 0 & 0 & 12 & 52 & 22 & 14 & 0 & 0 & 18 & 56 & 20 & 6 & 0.0867 \\
\hline Eggs & 0 & 22 & 34 & 30 & 8 & 6 & 0 & 4 & 32 & 32 & 20 & 12 & 0.0081 \\
\hline Vegetables & 12 & 28 & 22 & 28 & 6 & 4 & 28 & 16 & 28 & 20 & 8 & 0 & 0.0642 \\
\hline Potatoes & 36 & 32 & 32 & 0 & 0 & 0 & 16 & 20 & 40 & 24 & 0 & 0 & 0.3035 \\
\hline Potato dishes & 0 & 10 & 34 & 30 & 12 & 14 & 4 & 12 & 20 & 56 & 8 & 0 & 0.7377 \\
\hline Legume seeds & 0 & 0 & 2 & 28 & 36 & 34 & 0 & 0 & 4 & 16 & 44 & 36 & 0.0077 \\
\hline Fruits & 58 & 20 & 20 & 2 & 0 & 0 & 60 & 16 & 24 & 0 & 0 & 0 & 0.2470 \\
\hline Lard & 0 & 6 & 14 & 8 & 18 & 54 & 0 & 0 & 12 & 8 & 20 & 60 & 0.0800 \\
\hline Vegetable oils & 18 & 52 & 30 & 0 & 0 & 0 & 16 & 20 & 52 & 12 & 0 & 0 & 0.4845 \\
\hline Sweets & 30 & 24 & 34 & 12 & 0 & 0 & 8 & 20 & 20 & 20 & 12 & 20 & 0.2170 \\
\hline Nuts & 12 & 12 & 22 & 14 & 26 & 14 & 8 & 4 & 8 & 12 & 32 & 36 & 0.1214 \\
\hline Beer & 0 & 0 & 2 & 6 & 20 & 72 & 0 & 0 & 0 & 8 & 8 & 84 & 0.4530 \\
\hline Wine & 0 & 0 & 0 & 4 & 22 & 74 & 0 & 0 & 0 & 4 & 8 & 88 & 0.1113 \\
\hline Vodka & 0 & 0 & 0 & 0 & 14 & 86 & 0 & 0 & 0 & 0 & 0 & 100 & 0.0410 \\
\hline
\end{tabular}

en and $50 \%$ - obese women - the average age for the entire group was $52 \pm 5.3$ years of age. Among the subjects, $90 \%$ were married women with secondary or vocational education ( $50 \%$ and $24 \%$ of the experimental group, respectively). $28 \%$ of the subjects suffered from a single episode of depression, 2-4 episodes were observed in $15 \%$ of the subjects, 4 episodes of depression occurred in $57 \%$ of the subjects. $35 \%$ of the women received venlafaxine, $20 \%$ mirtazapine, $13 \%$ were treated with citalopram and another $13 \%$ with escitalopram and $105 / 10.5 \%$ sertraline and paroxetine. The average score on the Hamilton depression scale was 15.9 \pm 4.6 at baseline and $12.5 \pm 5.5$ after six months (the difference was not statistically significant). The average number of points scored on the Beck scale decreased from $27.6 \pm 12.0$ to $22.7 \pm 12.1$ (the difference was not statistically significant).

After 6 months of following the weight loss diet, a decrease in the average body weight by $4.1 \pm 3.1 \mathrm{~kg}$ was observed (Table I). The average BMI value decreased from $30.5 \pm 3.6$ to $29.5 \pm 3.0 \mathrm{~kg} / \mathrm{m}^{2}$. The body composition analysis revealed a reduction in the adipose tissue from $33.9 \pm 9.1$ to $28.9 \pm 1.4 \mathrm{~kg}$ and an increase in the fat-free body weight from $46.7 \pm 4.9$ to $47.6 \pm 4.4 \mathrm{~kg}$ (the difference was not statistically significant). The percentage adipose tissue content decreased 
Tab. III. Nutritional value of daily food rations of studied women before and after dietary intervention

\begin{tabular}{lccc}
\hline \multirow{2}{*}{ Variables } & Before intervention & After intervention & Mean \pm SD \\
\cline { 2 - 4 } & Mean \pm SD & $1596.7 \pm 376.0$ & 0.0234 \\
\hline Energy (kcal/day) & $1928.0 \pm 591.8$ & $57.9 \pm 22.6$ & 0.4990 \\
\hline Animal protein (g/day) & $61.2 \pm 21.6$ & $38.5 \pm 16.1$ & 0.9775 \\
\hline Total fat (g/day) & $38.4 \pm 19.2$ & $44.2 \pm 27.0$ & 0.5431 \\
\hline SFA (g/day) & $85.0 \pm 31.8$ & $24.1 \pm 13.3$ & 0.2316 \\
\hline MUFA (g/day) & $46.0 \pm 14.9$ & $15.5 \pm 11.0$ & 0.4768 \\
\hline PUFA (g/day) & $29.5 \pm 11.4$ & $4.6 \pm 2.6$ & 1.0000 \\
\hline Cholesterol (mg/day) & $9.5 \pm 3.7$ & $216.1 \pm 117.0$ & 0.4223 \\
\hline Carbohydrates (g/day) & $240.9 \pm 130.5$ & $241.3 \pm 83.9$ & 0.1420 \\
\hline Fibre (g/day) & $229.4 \pm 183.76$ & $17.5 \pm 7.0$ & 0.1155 \\
\hline Protein (\% E) & $15.4 \pm 6.2$ & $14.5 \pm 2.9$ & 0.5807 \\
\hline Total fat (\% E) & $12.7 \pm 4.2$ & $24.9 \pm 7.6$ & 0.1670 \\
\hline Carbohydrates (\% E) & $39.7 \pm 10.8$ & $59.4 \pm 6.7$ & 0.1627 \\
\hline
\end{tabular}

Tab. IV. Correlation coefficients between intensity of depressive symptoms, anthropometric features and daily energy and nutrients intake in studied women (after dietary intervention)

\begin{tabular}{|c|c|c|c|c|c|c|}
\hline \multirow[t]{2}{*}{ Variables } & \multicolumn{2}{|c|}{$\begin{array}{c}\text { Intensity of depressive symptoms } \\
\text { (Hamilton Depression Rating } \\
\text { Scale) }\end{array}$} & \multicolumn{2}{|c|}{ BMI $\left(\mathrm{kg} / \mathrm{m}^{2}\right)$} & \multicolumn{2}{|c|}{ Fat mass (\%) } \\
\hline & $r$ & $p$ & $r$ & $p$ & $r$ & $p$ \\
\hline Energy (kcal) & 0.1214 & 0.2400 & 0.0924 & 0.5230 & 0.0240 & 0.8690 \\
\hline Total protein (g) & 0.312 & 0.8800 & 0.0597 & 0.6800 & -0.0235 & 0.8710 \\
\hline Total fat (g) & 0.1776 & 0.3860 & 0.0529 & 0.7150 & 0.0262 & 0.8570 \\
\hline SFA (g) & 0.2153 & 0.2910 & 0.0573 & 0.6920 & 0.0870 & 0.5480 \\
\hline MUFA (g) & 0.1152 & 0.5750 & 0.0450 & 0.7560 & 0.0192 & 0.8950 \\
\hline PUFA (g) & 0.1384 & 0.5000 & -0.0673 & 0.6420 & -0.2063 & 0.1510 \\
\hline Carbohydrates & 0.0914 & 0.6570 & 0.0953 & 0.5110 & 0.0106 & 0.9420 \\
\hline Protein (\% E) & 0.2991 & 0.1380 & -0.0058 & 0.9680 & -0.0540 & 0.7090 \\
\hline Fat (\% E) & 0.1730 & 0.3980 & 0.0359 & 0.8040 & 0.0667 & 0.6750 \\
\hline Carbohydrates (\% E) & 0.1039 & 0.6130 & -0.0378 & 0.794 & -0.0420 & 0.7720 \\
\hline
\end{tabular}

from $40.2 \pm 5.4$ to $37.7 \pm 4.7 \%$ (the difference was not statistically significant). A reduction in the subcutaneous fat content by $2.6 \pm 2.4 \mathrm{~cm}^{2}$ and the visceral fat by $74.5 \pm 45.6 \mathrm{~cm}^{2}$ was also found (the difference was not statistically significant). The percentage water content in the body increased from $47.4 \pm 4.3$ to $48.8 \pm 3.0 \%$ (the difference was not statistically significant).

Table II presents the usual frequency of the consumption of selected products and dishes eaten by obese patients before and after the dietary intervention. It was found that the patients included in their diets wholemeal bread, grits, milk and dairy products, fish, vegetables and legume seeds too rarely. After using a six-month nutritional therapy, a significant increase in the wholemeal bread consumption was ob- served in the group of patients $(p=0.0475)$, lean pork $(p=0.0295)$ and legume seeds $(p=0.0077)$. It was concluded that the patients after the completed nutritional therapy consumed wheat bread $(p=0.0115)$, cream $(p=0.0117)$, fat pork $(p=0.0111)$ and eggs $(p=0.0081)$ more rarely. Also, the frequency of the consumption of lard and sweets decreased but these differences were not statistically significant.

Changes in the nutritional value and the content of selected nutrients in the patients' daily food intake during the dietary procedure are presented in Table III. After the completed dietary intervention, a decrease in the average energy value of the food intake was found from $1928.0 \pm 591.8 \mathrm{kcal} /$ day to $1596.7 \pm 376.0 \mathrm{kcal} /$ day (the difference was statistically significant). The total 
fat consumption was also reduced, on average by 40.8 $\pm 16.1 \mathrm{~g} /$ day, consumption of saturated fatty acids on average by $21.9 \pm 28.1 \mathrm{~g} /$ day, consumption of monounsaturated fatty acids on average by $14.0 \pm 13.1 \mathrm{~g} /$ day, consumption of polyunsaturated fatty acids on average by $4.9 \pm 3.8 \mathrm{~g} /$ day and the dietary cholesterol by 24.8 $\pm 113.6 \mathrm{mg} /$ day; the differences were not, however, statistically significant. The supply of carbohydrates increased in the subjects' diets on average by $12 \pm 78 \mathrm{~g} /$ day and dietary fibre by $2.1 \mathrm{~g} /$ day (the differences were not statistically significant). Also, a reduction in the percentage of energy from fat consumption and an increase in the percentage of energy from carbohydrates and proteins has been recorded, which may indicate a more frequent selection of low-fat protein products by the patients. Correlation analysis was used to evaluate the relationship among intensity of depression symptoms, anthropometric features and daily nutrients intake (Table IV). No correlation was found between depressive symptoms and daily energy and nutrients intake. Additionally, no significant correlation was found between body mass index and nutritional value of the diets. No significant correlation was found between fat mass (\%) and nutrients intake.

\section{Discussion}

A lot of researchers emphasize the link between depression and obesity and the conclusions drawn from these mutual relations are not unambiguous. Some of them treat depression as a consequence of low self-esteem and dissatisfaction with one's appearance. There are also those who treat obesity as a consequence of reduced activity resulting from depression and "consoling oneself" by eating and also as a complication of antidepression treatment. The invariably high indexes of the occurrence of depression among obese people are quoted (44-51\%) [12]. In numerous clinical studies, it was observed that the co-occurrence of depression and obesity is related to poorer results of attempts to lose weight, therefore, it is necessary to identify the relation between depression and obesity better to improve the quality of life and also the weight-loss effects [2].

In this study, after 6 months of using a weight-loss diet, an average decrease in the average body weight by $-4 \mathrm{~kg}$ was observed. It also results from the authors' own research that the average number of points of the Beck scale decreased from $27.6 \pm 12.0$ to $22.7 \pm 12.1$ (the difference was not statistically significant). In other studies, it was shown that the patients' body weight reduction on average by $3.51 \pm 5.9 \mathrm{~kg}$ was accompanied by alleviation of depression symptoms (changes in the Beck score on average by $-2.0 \pm 6.1$ points) [13]. In the presented studies, after the completed dietary intervention, the BMI was reduced. In research performed by Simon, it was observed that increased depression symptoms were related to a higher risk of obesity, while a higher $\mathrm{BMI}$ value was related to a higher risk of the occurrence of recurrent depressive disorders [14]. In the authors' own research, it was found that also a reduction in the average adipose tissue value both in percentage values and in kilograms, subcutaneous adipose tissue (SAT) and visceral adipose tissue (VAT) was observed, however the changes were not statistically significant. Perhaps this situation resulted from the size of the tested group. Williams obtained similar results - he found that recurrent depressive disorders occurred more frequently in obese persons with a higher BMI index, a higher fat content and a higher waist perimeter [15]. Akbaraly observed that the strongest predictors of depression included an increased volume of visceral adipose tissue, which was confirmed in research by other authors [16-18]. In the presented research, on the other hand, the average value of the fat-free body weight increased, both in kilograms and percentages. Other studies in women at the earlier stage of menopause point to positive effects of physical training not only for the body composition but also for physical condition. The studies among postmenopausal women showed that an increased number of steps per day is related to lower obesity as measured by the bioimpedance method (even in the case of controlling women's age and calories intake) [19].

The analysis of the frequency of the consumption of selected groups of food products showed that the most frequent mistake committed by the tested patients before the dietary intervention was eating wholemeal bread, grits, milk and dairy products, fish, vegetables and legume seeds too rarely. Our results were consistent with results of other studies [20], which showed numerous symptoms of a poor quality diet in this population. Similar results were obtained by Jastrzębska who showed in her research that everyday consumption of wholemeal bread was declared only by $22 \%$ of obese women, while grits were eaten by over $29 \%$ of the women taking part in the study only once a week. This author also showed that the consumption of milk and dairy products was declared by $37 \%$ of obese women [21]. An assessment of eating habits of obese patients suffering from depression showed a very low consumption of legume seeds, which are very rich in vitamin B, potassium, iron and magnesium, which was also confirmed in research by other authors [3, 22, 23]. After nutritional education, increased frequency of consumption of wholemeal bread, lean pork and legume seeds was observed among the patients. The frequency of the consumption of cream, fat milk and eggs was reduced. In the research conducted by Sanchez-Villegas, it was found that a high consumption of meat and meat products increases the risk of recurrent depressive disorders [24]. In the research by other authors, it was observed that food intake of patients suffering from depression 
was characterised by a low consumption of vegetables, dry legume fruits with simultaneous predominance of meat and animal fats [22, 23]. In studies by Park, it was shown that women suffering from depression ate products such as meat, fish, legume seeds less frequently and they consumed milk and dairy products more often as compared to women without depression [25]. In the presented own research, a small decrease in the frequency of consumption of lard and sweets has been stated, however, these differences were not statistically significant. The results of the research provide evidence that the eating style based on regular consumption of processed foods rich in refined cereal products, sweets and high-fat dairy products is related to a more frequent occurrence of depressive episodes and obesity as opposed to an eating style based on more frequent consumption of fruits, vegetables and fish, which was related to a lower occurrence of depressive episodes and obesity [16]. Epidemiological data indicate the existence of a relation between fish consumption in individual regions of the world and the occurrence of depression [26]. It was found that frequent consumption of fish and seafood was related to a reduced risk of single and recurrent episodes of depression [26]. Research conducted in Spain on a large group of people showed that strict compliance with the Mediterranean diet based on high consumption of vegetables, fruits, grits, fish and legume seeds was related to a lower frequency of depression [24].

Changes in the frequency of the consumption of selected food products were also accompanied by changes in the energy and nutritional value of wholeday food intake. After the completed nutritional intervention, a decrease in the average energy value of the food intake from $1928.0 \pm 591.8 \mathrm{kcal} /$ day to 1596.7 $\pm 376.0 \mathrm{kcal} /$ day was found. The results obtained in other studies show that too high an energy value of a diet as compared to the demand may be a potential mediator of the relations between obesity and depression $[14,25]$. The energy value of a diet similar to the energy value of the diet obtained before the nutritional education in the presented results was also obtained by Grossniklaus (1899.8 $\pm 490.9 \mathrm{kcal} /$ day) [23]. In other studies which assessed the eating style of depression patients, on the other hand, a considerably lower calorie value of the diet was obtained $1524.5 \pm 46.5 \mathrm{kcal} /$ day [25]. In the food intake of the subjects, the supply of proteins was too high as compared to the demand, both before and after dietary intervention. In research by other authors, the average protein content in the food intake of subjects suffering from depression differed slightly from the values presented in this study and it was equal to 59.2 g/day in Park's study and $69.1 \mathrm{~g} /$ day in Grossniklaus's study [23, 25]. In the presented research, the fat supply was too high as compared to the demand at the beginning of the dietary therapy - $85 \pm 31.8 \mathrm{~g} /$ day in total, however, after the end of the intervention, the fat supply was reduced to $44.2 \pm 27.0 \mathrm{~g} /$ day. After 6 months of the dietary therapy, a clear decrease in the excessive supply of saturated fatty acids was also observed from $46 \pm 14.9 \mathrm{~g} /$ day to $24.1 \pm 13.3 \mathrm{~g} /$ day. Appelhans concluded in his studies that the nutritional style of obese patients suffering from depression was characterized by too high consumption of saturated fatty acids and too low consumption of polyunsaturated fatty acids [22]. Similar results were observed by Sanhueza [27]. In the authors' own research, a low consumption of mono- and polyunsaturated fatty acids should be also emphasized both at the beginning and at the end of the study. The food intake of depression sufferers is very often characterised by an incorrect structure of fatty acid consumption with too high consumption of saturated fatty acids $[24,27]$. It was found that an increased incidence of depression occurs in regions with low consumption of omega 3 acids which results from rare consumption of fish [26], which was also confirmed in the presented results. In an assessment of carbohydrate consumption in the food intake of the subjects, the supply of carbohydrates was too low as compared to the demand [28], both before and after dietary intervention. A diet rich in carbohydrates contributes to changes in insulin and glucose levels in the blood, which stimulates the release of tryptophan from protein and its further conversion to a serotonin neurotransmitter [29]. On the other hand, a high content of carbohydrates in the diet, in particular, simple ones may promote obesity [30]. On the basis of his research, Appelhans observed that depression was related to poorer quality of the diet, namely, with a higher percentage of energy from saturated fats and simple carbohydrates [22].

In the present study, no significant correlation was found between depressive symptoms, anthropometric features and daily energy and nutrients intake. However, a correlation between intensity of depressive symptoms and majority of nutrients intake was positive. Most of the studies have shown a positive correlation between the body mass index and excessive intake of dietary fats $[4,7]$. On the other hand, the findings support the notion that the negative association commonly observed between fat mass and daily protein and carbohydrates intake (expressed as a percentage of total energy intake) explained benefits of increasing dietary intake of carbohydrates. In the presented studies, after the completed dietary intervention, the anthropometric features and average daily intake of majority of nutrients was reduced.

The long-term effect of the nutritional therapy performed indicates the need for intensive dietary education, including more diet-related trainings and intensified cooperation between patients and dieticians for correct selection of food products. 


\section{Conclusions}

It seems that the dietary procedure which is aimed at obtaining the most advantageous effects of the reduction in the body mass of obese patients suffering from depression should be based not only on reduction in the energy and nutritional value of the diet, but it should also take into account actions aimed at introducing changes in the eating habits.

Proper nutritional education aimed at this group of patients may contribute to changes in the eating style and, as a result, to gradual reduction in the body weight and improved quality of life.

\section{Disclosure}

\section{Authors report no conflict of interest.}

\section{References}

1. Jarząbek-Bielecka G, Wilczak M, Potasińska-Sobkowska A, et al. Overweight, obesity and female sexuality in perimenopause: a preliminary report. Prz Menopauzalny 2015; 14: 97-104.

2. McCrea RI, Berger YG, King KB. Body mass index and common mental disorders:exploring the shape of the association and its moderation by age, gender and education. Int J Obes 2012; 36: 414-421.

3. Jacka FN, Cherbuin N, Anstey KJ, Butterworth. Does reverse causality explain the relationship between diet and depression? J Affect Disord 2015; 175: 248-250.

4. Ostrowska L, Stefańska E, Adamska E, et al. Effect of treatment with reducing diet on body composition and modification of nutrients in daily food intake of obese women. Endokr, Otyłość i Zab Przem Mat 2010 6: 179-188.

5. Brończyk-Puzoń A, Piecha D, Nowak J, et al. Guidelines for dietary management of menopausal women with simple obesity. Prz Menopauzalny 2015; 14: 48-52.

6. World Health Organization. Depression. http://www.who.int/mental_health/management/depression/definition/en/idex1.html (access: 2012 October).

7. Olszanecka-Glinianowicz M. Depresja - przyczyna czy skutek otyłości? Endokr Otyłość i Zab Przem Mat 2008; 4: 78-85.

8. International statistical classification of diseases and health-related problems. 10th rev. World Health Organization, Geneva 1992.

9. Hamilton M. A rating scale for depression. J Neurol Neurosurg Psychiatry 1960; 23: 56-62.

10. Beck AT, Ward CH, Mendelson M, Mock J, Erbaugh J. An inventory for measuring depression. Arch Gen Psychiatry 1961; 4: 53-63.

11. Szponar L, Wolnicka K, Rychlik E. Album fotografii produktów i potraw. Instytut Żywności i Żywienia, Warszawa 2000.

12. Paliga J, Oleksiak A, Lukas W, et al. Is clinical depression really more prevalent among morbidly obese patients? Probl Med Rodz 2014; 3 : 12-17.

13. Ruusunen A, Voutilainen S, Karhunen L, et al. How does lifestyle intervention affect depressive symptoms? Results from the Finnish Diabetes Prevention Study. Diabet Med 2012; 29: 126-132.

14. Simon GE, Ludman EJ, Linde JA, et al. Association between obesity and depression in middle-aged women. Gen Hosp Psychiatry 2008; 30: 32 39.

15. Williams LJ, Pasco JA, Henry MJ, et al. Lifetime psychiatric disorders and body composition: A population-based study. J Affect Disord 2009; 118: 173-179.

16. Akbaraly TN, Brunner EJ, Ferrie JE, et al. Dietary pattern and depressive symptoms in middle age. Br J Psychiatry 2009; 195: 408-413.

17. Weber-Hamann B, Werner M, Hentschel F. Metabolic changes in elderly patients with major depression: evidence for increased accumulation of visceral fat at follow-up. Psychoneuroendocrinology 2006; 31: 347-354.
18. Wysokiński A, Kłoszewska I. Metabolic syndrome and depressive disorders - literature review. Psychiatry 2011; 8: 46-52.

19. Kroemeke A, Zając-Gawlak I, Pośpiech D, et al. Postmenopausal obesity:12,500 steps per day as a remedy? Relationships between body composition and daily steps in postmenopausal women. Prz Menopauzalny 2014; 13: 227-232.

20. Davison KM, Kaplan BJ. Nutrient intakes are correlated with overall psychiatric functioning in adults with mood disorders. Can J Psychiatry 2012; 57: 85-92.

21. Jastrzębska-Mierzyńska M, Ostrowska L, Hady HR, Dadan J. Dietary habits of obese patients qualified for bariatric procedures. Rocz Panstw Zakl Hig 2014; 65: 1-8.

22. Appelhans BM, Whited MC, Schneider KL, et al. Depression severity, diet quality, and physical activity in women with obesity and depression. J Acad Nutr Diet 2012; 112: 693-698.

23. Grossniklaus DA, Dunbar SB, Tohill BC, et al. Psychological factors are important of dietary pattern in overweight adults. J Cardiovasc Nurs 2010; 25: 450-460.

24. Sànchez-Villegas A, Delgado-Rodriguez M, Alonso A, et al. Association of the Mediterranean dietary patern with the incidence of depression: the Seguimiento Universidad de Navara/University of Navara follow-up (SUN) cohort. Arch Gen Psychiatry 2009; 66: 1090-1098.

25. Park JY, You JS, Chang KJ. Dietary taurine intake, nutrients intake, dietary habits and life stress by depression in Korean female college students: a case-control study. J Biomed Sci 2010; 24: 40-44.

26. Hakkarainen R, Partonen T, Haukka J, et al. Food and nutrient intake in relation to mental wellbeing. Nutr J 2004; 3: 14-18.

27. Sanhueza C, Ryan L, Foxcroft DR. Diet and the risk of unipolar depression in adults: systematic review of cohort studies. J Hum Nutr Diet 2013; 26: 56-60.

28. Jarosz M, Bułchak-Jachymczyk B. Normy żywienia człowieka. Podstawy prewencji otyłości i chorób niezakaźnych. Wyd. Lek. PZWL, Warszawa 2012.

29. Sugawara N, Yasui-Furukori N, Tsuchimine S, et al. No association between dietary patterns and depressive symptoms among a community - dwelling population in Japan. Ann Gen Psychiatry 2012; 11: 24-31.

30. Aparicio A, Robles F, Lŏpez-Sobaler AM, Ortega RM. Dietary glycaemic load and odds of depression in a group of institutionalized elderly people without antidepressant treatment. Eur J Nutr 2013; 52: 1059-1066. 